\title{
Plum Pox Virus (PPV) Dispersion in Plum Trees (Prunus domestica. L) CV. D'Agen
}

\author{
Laura Porcel, Cecilia Picca, Carlos Fuentes and Eva Ojeda \\ Estación Experimental Agropecuaria Rama Caída, INTA (Instituto Nacional de Tecnología Agropecuaria), El Vivero S/N, Rama \\ Caída, San Rafael 5600, Mendoza, Argentina
}

\begin{abstract}
Sharka, it is considered one of the most serious diseases of stone fruits worldwide. It is transmitted long distances by propagating material and by aphids close to an infection focus. In San Rafael, Mendoza, Argentina, it made a study of dispersion's degree of the disease in a plum plantation CV D'Agen. Samples were taken in the spring of the basal part of open leaves. A DAS-ELISA test was made using a protocol in agreement with SENASA and INASE (2007) on 750 plants. Infection percentages found were $4.4 \%$; $6.4 \%$; $8.53 \%$ and $10.1 \%$; between the first until last year of study. These numbers indicate a degree of dissemination of the disease similar than described by the Chileans and slower than described by the Spanish and French. Several factors can be responsible for the speed of dispersion of diseases like Sharka: vector quantities, presence of parasites and predators, closeness to inoculants sources, different degree of susceptibility of the species or cultivar to the disease or insect or others. This work can serve as a base for further studies on the incidence of diverse factors in the process of disease dispersion.
\end{abstract}

Key words: Dissemination, stone, stone fruit, virus disease, PPV.

\section{Introduction}

Sharka is considered the most important virus disease in stone fruit trees. The infection causes an important reduction of fruit production. The presence of PPV (Plum pox virus) can also enhance the effects of other endemic virus infections in several species of genus Prunus, such as PDV (Prunus dwarf virus), PNRSV (Prunus necrotic ringspot virus) and ACLSV (Apple chlorotic leaf spot virus), resulting in even greater economic losses. Three factors of this disease constitute a serious problem: vector's dissemination, severe injuries in fruit that make it not marketable and so many varieties are susceptible to it [1]. Also the presence of PPV can cause premature drop of fruit.

The origin of PPV is in Eastern Europe (Bulgaria, Dr. Dimitar Atanasov 1932) and was spread to most of the continent (OEPP/EPPO, 1974). Until recently, no case had been reported from outside the EURO-Mediterranean area, but PPV has now been

Corresponding author: Laura Porcel, agricultural engineer, research fields: vegetal protection, virology, fruit and horticultural production. found in India (1994), eastern countries of Europe, Mediterranean countries (Albania, Cyprus, Egypt, Greece, Italy, Portugal, Spain, Syria and Turkey), northern and western countries (Austria, Germany, England, Belgium; France and Luxemburg); and in South America (Chile 1992, Argentina 2004) [2]. In 2009, it was detected in Japan [3].

PPV is a virus of genus Potyvirus, family Potiviridae, with a 725 at $760 \mathrm{~nm}$ per $20 \mathrm{~nm}$ filament genoma. Heterogeneous distribution inside the affected plants increases the difficulties for its diagnosis. The incubation period can be nine or thirteen months and systemic propagation in the whole plant can happen in between two or three years in small trees. It is possible to distinguish different strain, some as $\mathrm{D}$ (Dideron), $\mathrm{M}$ (Marcus), EA (El Amar), C (Cherry), Rec (Recombinant) ,W (Winona) and T [1]. PPV strain D (Dideron) was isolate in France and is common in Europe, USA, Chile and Argentina. It's characterized because it is not transmitted by seed. It affects in the same severe form peaches, apricots and plums. It presents difficulties when working with experimental 
transmission of host, there is little efficiency in vectors transmission and it is considered non-epidemic form of PPV.

In natural conditions PPV infects fruit trees of genus Prunus, peaches, nectarines, apricot, european plum and japanese plum, cherry, sour cherry, almond, and ornamental Prunus [4]. These plants are sources for futures infections. Spontaneous weeds can be host, but they are insignificant as virus reservoir [5].

This disease is impossible to control once a tree becomes infected, and they must be destroyed. Once the disease becomes established, control and prevention measures for plum pox include field surveys, use of certified nursery material, control of aphids (vectors) and elimination of infected trees in nurseries and orchards.

From first report of Sharka in Argentina [2], a network was made between Estate Organisms: SENASA (Servicio Nacional de Sanidad y Calidad Agroalimentaria), INASE (Instituto Nacional de Semillas) and INTA (Instituto Nacional de Tecnología Agropecuaria), to learn about the disease, its diagnosis and control. The first goal of this network was the eradication of sick plants, delimitation of quarantine areas, control of movement for fruit trees, official analysis for determination of PPV in nursery fruit trees before its multiplication and specific rules for interdiction areas (SENASA Resolución 24/2005).

The virus is spread to long distances with the movement of infected plant material, plants or parts of them like bud or stick, between countries or region without legal control [6]. Once, introduction has occurred, the dissemination in the local place is for the action of more than 20 aphid's species. These aphids can be natural vectors because they taste or feed on infected leaves, after they fly to other trees where they taste again or feed, spreading PPV between fruit trees [1]. PPV can be spread efficiently for species that colonize or not stone fruit trees [7]. The literature cited Myzus persicae, Aphis gossipy and Aphis craccivora like more efficient vectors of PPV [8]. In general the speed of virus spread depends on efficient transmission of aphids more abundant in the local place, production of wings forms of the insects, predominant winds and source of inoculum (weeds and susceptible variety of fruits trees).

In a parcel of Prunus domestica, L cv. D’Àgen located in the Estación Experimental Rama Caída-INTA in San Rafael, Mendoza, Argentina, found ill plants during 2007, the percentage of illness was $2.53 \%$. This group of 750 trees was analyzed every year and the plants with positive result were eradicated. The accumulate percentage of trees with PPV in 2008 was $4.40 \%$, in 2009 was $6.40 \%$, in 2012 was $8.53 \%$ and in 2015 after 8 years of first detention was $10.1 \%$. The evaluation of the spatial distribution of sick plants in the first identification, during 2007, showed that they were in west border of the field and gradually spread from there. Sick plants appeared year after year close to the first detection. Plum trees were detected leaf's symptoms such as chlorosis, and ring spots (Fig. 1), but the symptoms were never detected in fruits [9].

After 8 years, sick plants with greatest concentration continue near the first detection of PPV and detection continues with identification of plants at short distance of them. The sick trees distribution in the border at first time, with spread at short distance time to time, suggests external and near focus of inoculum, and aphid activity. Spread velocity of virus is less than description in Spain, when it is necessary 2 at 5 years for $100 \%$ of dissemination [10], or France, where it indicates 8 to 9 years for $100 \%$ of contamination [11]. Something similar occurs in Chile with $26 \%$ of dispersion in 4 years in apricot susceptible variety [12].

Preceding ideas suggest that in this place the aphid's behavior like vectors are not so efficient. Moreover, population of aphids is low in the field of this study. It is possible to speculate that ecological or climatic conditions help the tolerance or resistance of Prunus and the conservative use of pesticide can contribute to the maintenance of ecologic equilibrium. 


\section{Objective}

This study is aimed to research the natural spread of Sharka virus disease in European plum trees (Prunus domestica L. cv DÀgen), in south of Mendoza province, Argentina.

\section{Materials and Methods}

It was utilized 750 plum trees (Prunus domestica L. cv D’Agen) grafted onto mirabolán rootstocks, cultivated in 1 ha in Estación Experimental Agropecuaria Rama Caída (INTA) of San Rafael district, located in south of Mendoza province of Argentina. Plum trees were detected PPV's leaf's symptoms such as chlorosis and ring spots, never in fruits. The total of plants was sampling for following the spread disease throw the ELISA's technique.

In spring season (middle of October) of the years 2007; 2008; 2009; 2012 and 2015, it was sampling leaves of branches at four cardinal points in all the plants of the field. The sampling was made early in the morning and was maintained at low temperature $\left(10^{\circ} \mathrm{C}\right)$ until grinding moment.

Serological test DAS-ELISA was made utilizing BIOREBA reagent and Protocol INTA-SENASA-INASE, 2007 for monitory and control of PPV. It is coating the micro-plates whit dilution 1:1000 of IgG/buffer, utilized 10 $\mathrm{mL} /$ microplate and $37^{\circ} \mathrm{C}$ for incubation during $3 \mathrm{hrs}$. For leaf samples, utilized $0.5 \mathrm{~g}$ of $1 / 3$ leaf basal diluted in $5 \mathrm{~mL}$ of extraction buffer with $2 \mathrm{~g} / \mathrm{L}$ of DIECA, incubation at $4{ }^{\circ} \mathrm{C}$ during 18-24 hrs. Conjugate was diluted 1:1,000 in buffer, 3 hrs for incubation at $37^{\circ} \mathrm{C}$, and substrate p-NPPNa was utilized at $1 \mathrm{mg} / \mathrm{mL}$ concentration, $1 \mathrm{hr}$ incubated at ambient temperature. Each sample was duplicated; for positive control was utilized identified carrier PPV plum trees; for negative control utilized identified healthy plum's plants and negative controls from BIOREBA. Reaction was reading with Absorbance Microplate Reader ELX800, BIO-TEK at $405 \mathrm{~nm}$, considered positives the lectures whit doubles values or more of healthy average.

With result of reactions, it was possible to make a graphic that shows the increase of sickness in the field of plum's trees and their spread (Table 1 and Fig. 2).

\section{Results}

First positives plants detected in EEA Rama Caída in 2007, were located at west border of field, then were found new PPV carrier in consecutive years, concentrates nearly to the first, it is observed coincidence in this movement whit the main direction of the winds in this place (Fig. 3). Infection percentages were 2.53\% (2007); $4.13 \%$ (2008); $5.73 \%$ (2009); 8.27\% (2012) and 9.73\% (2015). This percentage near to $10 \%$ accumulated in 8 years, indicates that the speed of dispersion is slower than observed in France (8 at 9 years for 100\%) and in Spain (2 at 5 years for $100 \%$ ). In Chile it was registered low speed of infection [12].

Table 1 Accumulation amount of sickly plants (plums cv. DÁgen) of PPV between 2007 and 2015 years.

\begin{tabular}{lllllllllllllllllllllllllll}
\hline Year/row & 1 & 2 & 3 & 4 & 5 & 6 & 7 & 8 & 9 & 10 & 11 & 12 & 13 & 14 & 15 & 16 & 17 & 18 & 19 & 20 & 21 & 22 & 23 & 24 & 25 \\
\hline 2007 & 5 & 5 & 3 & 2 & 1 & 0 & 1 & 0 & 1 & 0 & 0 & 1 & 0 & 0 & 0 & 0 & 0 & 0 & 0 & 0 & 0 & 0 & 0 & 0 & 0 \\
2008 & 6 & 11 & 4 & 2 & 1 & 0 & 1 & 0 & 1 & 0 & 0 & 4 & 1 & 0 & 0 & 3 & 0 & 0 & 0 & 0 & 0 & 0 & 0 & 0 & 0 & \\
2009 & 8 & 12 & 9 & 2 & 3 & 0 & 1 & 0 & 1 & 0 & 0 & 5 & 1 & 0 & 0 & 3 & 0 & 0 & 0 & 2 & 0 & 0 & 0 & 1 & 0 \\
2012 & 9 & 17 & 11 & 3 & 3 & 0 & 2 & 0 & 2 & 1 & 1 & 6 & 2 & 1 & 0 & 3 & 0 & 0 & 0 & 2 & 0 & 0 & 0 & 1 & 0 \\
2015 & 11 & 19 & 12 & 7 & 3 & 1 & 3 & 0 & 2 & 1 & 1 & 6 & 2 & 2 & 0 & 3 & 0 & 0 & 0 & 2 & 0 & 0 & 0 & 1 & 0 \\
\hline
\end{tabular}




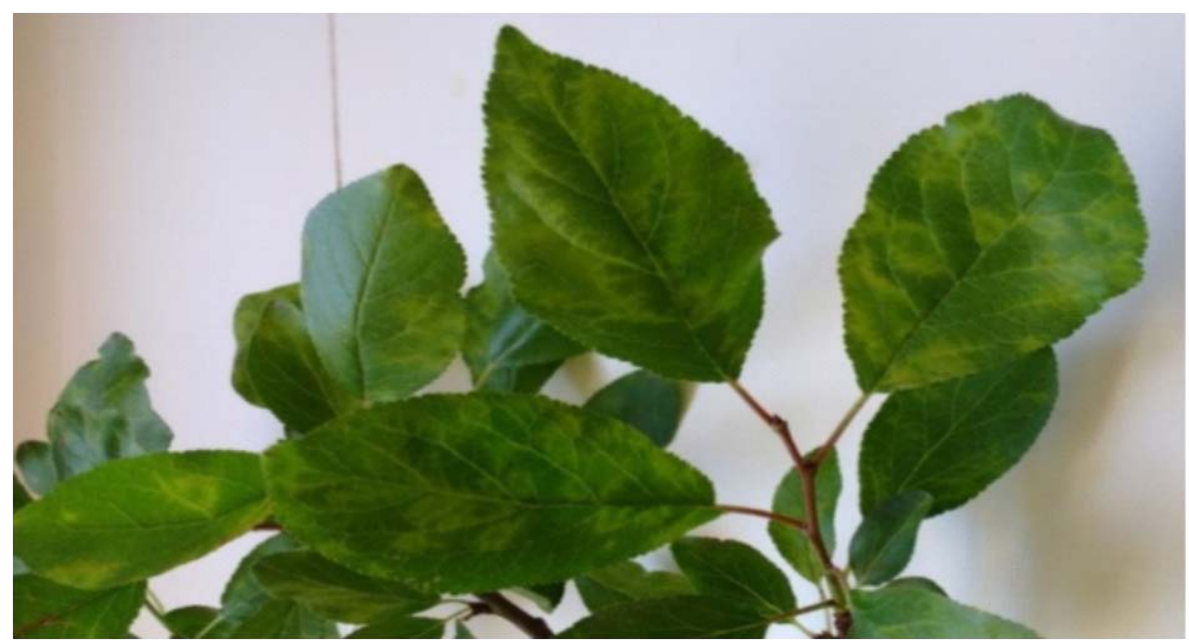

Fig. 1 Leaf's symptoms of PPV: ringspot and chlorosis



Fig. 2 Accumulated sick PPV plants in a period of eight years. 

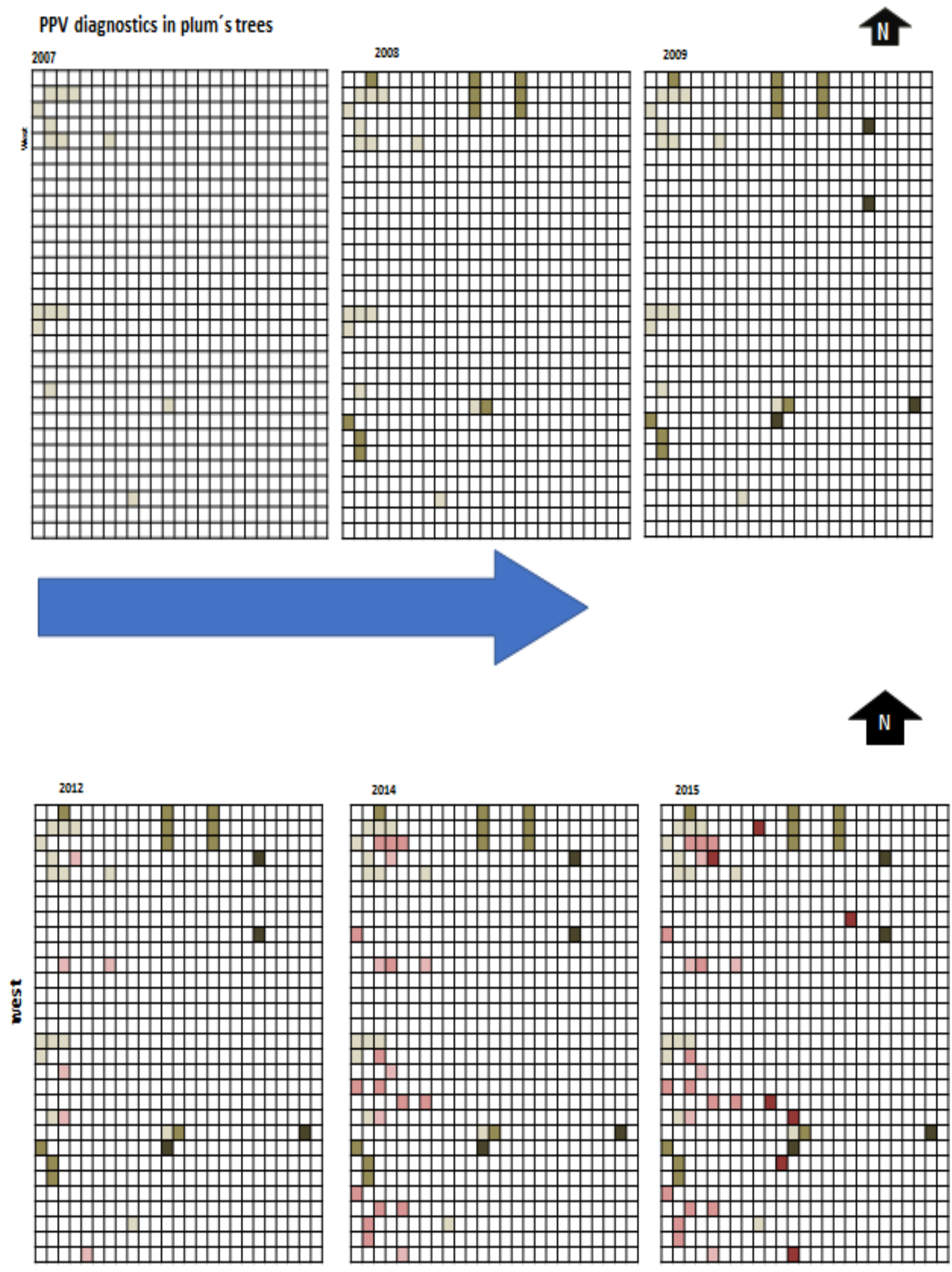

Fig. 3 PPV dispersion from west, and near to the first detection. 


\section{Discussion}

According to the result of this work, it can be deduced that PPV was spread in natural form in plum field of this study, with lower speed than reported in Spain, France and Chile. The spatial distribution observed and the spread at short distance could be due to external inoculum and active non-efficient vectors. It is possible to speculate that the short time with low temperatures in spring provokes early aphids migrations in prunus, or that the population of biological control is adequate according to the amount of aphids. Other reason can be that the strain of virus is only one or maybe the focus of first plants was small. The causes of this disease behavior can be related with climatic characteristic of the area like great thermal amplitude, windy spring or others that could be evaluated in the future. Other causes could be due to characteristics of different cultivars and clones, for a different strain of virus or with the interaction arthropod fauna-cultivation.

\section{Conclusions}

Various factors can be responsible for the speed of dispersion of diseases like Sharka: vector quantities, presence of parasites and predators, closeness to inoculants sources, degree of susceptibility of the species and or cultivar to the disease and or insect or others. It is important to know the factors that affect the slow velocity of dissemination of this disease, we need to learn more about the vector's and biologic's controller and their ecological conditions of life. This work can contribute as a base for further studies on the incidence of diverse factors in the process of disease dispersion.

\section{Reference}

[1] Barba, M., A., Hadidi, T., Cyresse, and M. Cambra. 2011. "Plum pox virus." In Virus and Virus-Like Diseases of Pome and Stone Fruits. Edited by Hadidi, A., Barba, M., Candresse, T., and Jelmann, W. St. Paul. MN: The American Phytopathological Society, pp. 185-97.

[2] Dal Zotto, A., Ortego, J., Raigon, J., Caloggero, S., Rossini, M., and Ducasse, D. 2006. "First Report in Argentina of Plum Pox Virus Causing Sharka Disease in Prunus.” Plant Disease 90 (4): 523.

[3] Maejima, A., et al. 2010. "First Report of Plum pox virus Strain M in Japan.” Accessed on November 10, 2010. http://www.pps.go.jp/english/pestreport/index.html.

[4] ISPM 27. Annex 2. Plum pox virus (2012) Rome. IPPC. FAO. International Plant Protection Convention.

[5] Levy, L., Damsteegt, V., Scorza R., and Kolber, M. 2000 "Plum Pox Potyvirus Diseaseof Stone Fruits." APSnet Features. Online. Doi: 1.094/APSnetFeature-2000-0300.

[6] Auger, J., and Esterio, M. 1995. "La enfermedad de la Sharka (Plum pox Virus) en Chile.” Rev. Aconex. 47: 25-8.

[7] Labonne, G., and Dallot, S. 2006. "Epidemiologia de Sharka en Francia.” EPPO. Bull. 36 (2): 267-70.

[8] Muñoz, M., and Collao, M. 2006. "Plum pox virus in Chile.” Bulletin OEPP/EPPO 36: 205.

[9] Marini, D., Farrando, R., Ojeda, M., and Porcel, L. 2010. "Estudio de la detección del virus del Sharka en las diferentes partes del fruto en ciruelo europeo (Prunus domestica L.) a través de la técnica serológica DAS-ELISA. XXXIII Congreso Argentino de Horticultura. Rosario. Argentina.” ISBOIS NOIR 978-987-97812-6-5. p. 182.

[10] Llacer, G., and Cambra, M. 1998. "Thirteen Years of Sharka Diseases in Valencia, Spain.” Acta Horticulture 4: 384.

[11] Adamolle, C., Boeglin, M., Labonne, G., Candrese, T., and Quiot, J. 1994. "Une souchenecrogene du plum pox potyirus provoque un deperissement sur certains cultivars de pecher.” OEPP/EPPO Bull. 24: 721-30.

[12] Herrera Guido, M., and Madariaga, M. 2003. "Diseminación natural del virus causante de la enfermedad de Sharka (Plum Pox Virus) en tres temporadas en un huerto de damasco.” Agricultura Técnica 63 (2). (in Chillán) 